\title{
IMPROVING SOME ECONOMIC TRAITS OF CARAWAY (Carum carvi, L.) THROUGH MASS SELECTION El-Labban, H.M.*;A.A.Gad ${ }^{\star *} ;$ F.A.Sadek*and Rasha S.F. El-Serafy* * Horticulture Dept., Fac. Agriculture, Tanta University, Egypt. \\ ${ }^{* *}$ Horticulture Dept., Fac. Agriculture., Zagazig University, Egypt.
}

\begin{abstract}
The present study was carried out at the Experimental Farm of the Faculty of Agriculture, Tanta University, during three successive winter seasons (2006/2007, $2007 / 2008$ and 2008/2009). In order to improve caraway population in growth characters and fruit yield; two cycles of mass selection were done. The base population $\left(\mathrm{C}_{0}\right)$ from the local variety (Balady) seeds were sown on rows $75 \mathrm{~cm}$ apart and $50 \mathrm{~cm}$ between hills. At maturity stage, selection was done on the basis of high yielding $20 \%$ of the plants. Fruits of previous selected plants were bulked together and sown to raise the next generation $\left(C_{1}\right)$. At the end of $C_{1}$ and $C_{2}$ the selection intensity was raised to about $40 \%$. Each selected plant fruits were weighted and oil content was determined. The results of this study showed that mass selection led to increase homogeneity of plant height and number of branches / plant with reduces the variability.

Concerning fruit yield the results also, declared that the fruit yield/ plant was increased from $\mathrm{C}_{0}$ to $\mathrm{C}_{2}$, although the decreased of volatile oil percentage from $\mathrm{C}_{0}$ to $\mathrm{C}_{2}$, without significant differences between the three population.

In the future more than two cycles are needed for continuous improvement in yield/plant and the percentage of volatile oil.

Keywords: Caraway, Carum carvi, L., mass selections, breeding, vegetative growth, fruit characters and oil content.
\end{abstract}

\section{INTRODUCTION}

Caraway (Carum carvi, L.) plant is an annual herbaceous plant belongs to Family Apiaceae and widely distributed in countries bordering Europe, western Asia, and northern Africa. The caraway fruit is a schizocarp, which at harvest is separated into halves, which are called "seeds". (Harro et al., 1998). Caraway seeds have an aromatic fresh taste and smell caused by an essential oil contained in ducts in the pericarp.

The economical importance of caraway plants is attributed to its seeds which contains about $3-5 \%$ volatile oil. The aroma of the oil is mostly dominated by carvone (50 to $60 \%$ ) and limonene (20 to $30 \%$ ), the principal content of oil in addition to trace amount of other constituents (carveol, dihydrocarveol, $\alpha$ - and $\beta$ - pinene, sabinene and perillyl alcohol) are of much minor importance (Baysal and Starmans, 1999).

The oil has several uses for the flavouring of pharmaceutical products, such as tooth paste, and the oil is applied to treat flatulence, stomach disorders, antihistaminic to relieve gas and as antispasmodic.

The seeds use as a culinary in food industries (pickles and bread), Carvon from essential oil use as a sprout-inhibiting agent for potatoes and seed potatoes, Baysal and Starmans, 1999 and Oosterhaven et al., 1995). 
In the Mediterranean region, caraway varieties that seem to be originate from local populations or their origin is unknown, are called "Balady". These types became the source of varieties for selection of new types whereas this type as a cross pollinated species has a genetic heterozygosity. So, it is appeared suitable for improvement, through selecting better genotypes for agronomic and quality traits.

National Research Centre on Seed Spices (2007) has developed two annual types of caraway selections NRCSS-ACar-91 and ARCSS-ACar-94, both of these selections are being acclimatized for cultivation under semi-arid conditions. Petraityte et al. (2002) investigated the stability of some morph biochemical parameters of common caraway. They found that the most stable parameter was 1000-fruit weight. Kuz-mich (1986) mentioned that individual plant selection in a local population of Carum carvi from kiev (Ukraine), gave population exceeds the standard by $0.32 \mathrm{t} / \mathrm{ha}$ in seed yield.

Dusek (1992) illustrated that from 21 Carum carvi genotypes evaluated over 2 years, the seed yield was improved from $2.6 \mathrm{t} /$ /ha in 1988 to $4.6 \mathrm{t} / \mathrm{ha}$ in 1989. Kuź-mich (1986) mentioned that individual selection in a local population of Carum carvi from Kiev (Ukraine) exceeds the standard by $0.44 \%$ in essential oil content and by $20.3 \mathrm{~kg} / \mathrm{ha}$ in essential oil yield.

In Egypt, medical and aromatic plants have a little improvement and breeding research. So, the main objective of this work was to evaluate some figures of caraway population as affected by mass selection.

\section{MATERIALES AND METHODS}

The present study was carried out at the Experimental Farm of the Faculty of Agriculture, Tanta University, during three successive winter seasons (2006/2007, 2007/2008 and 2008/2009). This study was initiated to improve caraway (Carum carvi, L.) population through using two cycles of mass selection.

The seeds were obtained from the Medical and Aromatic Plants Department, Horticulture Research Institute, Agriculture Research Center, Ministry of Agriculture, Egypt.

The base population $\left(\mathrm{C}_{0}\right)$

The experimental soil was divided into rows $75 \mathrm{~cm}$ apart. Seeds of caraway were sown on the $4^{\text {th }}$ of November during 2006/2007 season in hills, 3-4 seeds per hill. The distance between hills was $50 \mathrm{~cm}$. After the full germination (about 2 weeks), the seedlings were thinned to maintain one plant in each hill. Fertilizers were applied as recommended by Ministry of Agriculture, Egypt.

The recommended dose (RD) used of NPK chemical fertilizers was 400 $\mathrm{kg} / \mathrm{fed}$. Ammonium Sulphate (20.5\%), calcium super phosphate $300 \mathrm{~kg} / \mathrm{fed}$. $\left(15.5 \% \mathrm{P}_{2} \mathrm{O}_{5}\right)$ and $50 \mathrm{~kg} / \mathrm{fed}$. potassium Sulphate $\left(48 \% \mathrm{~K}_{2} \mathrm{O}\right)$. Ammonium Sulphate was added in two equal doses, the first one was added after month of sowing, then the second one was added after month of the first one, while calcium super phosphate and potassium sulphate were added during soil preparation. All other cultural practices were done whenever required. 
At maturity stage, each plant on the $5^{\text {th }}$ of May was individually harvested, and its weight was recorded after it has been air-dried. Twenty three individual plants were selected on the basis of their fruit yield / plant, when they ranged about (33.64 - 49.97g /plant) and oil contents were ranged about $(1.30-3.50 \%)$. An equal quantities of seeds from the selected plants (23 plant) were bulked together to raise the next generation.

The first cycle of mass selection $\left(C_{1}\right)$

The bulked fruits were sown on the $6^{\text {th }}$ of November during 2007/2008 season and the same cultural practices were done as previously mentioned in $\mathrm{C}_{0}$ population. Each plant on the $9^{\text {th }}$ of May was individually harvested.

On the basis of fruit yield / plant and oil content, thirty eight individual plants yielded (21.98 - $59.92 \mathrm{~g} /$ plant) fruit yield, and (2.0 - $3.5 \%)$ oil content were selected. Then equal quantities of the fruits from the selected plants were bulked to raise the next generation.

The second cycle of mass selection $\left(C_{2}\right)$

The bulked fruits were sown on the $6^{\text {th }}$ of November during 2008/2009 season. After harvest, each plant on the $11^{\text {th }}$ of May was individually harvested. Thirty six individual plants were selected, these plants yielded (26.55 - 52.47 g / plant) and oil content (2.1 - $3.5 \%)$.

Data recorded on individual plants in each generation:

1. Vegetative characteristics

1.1 Plant height $(\mathrm{cm})$.

1.2 Branch number/plant.

2. Fruit Characteristics

2.1100 fruits weight $(\mathrm{g})$.

2.2 Fruit yield / plant $(\mathrm{g})$.

3. Volatile Oil

3.1 Oil percentage \%.

3.2 Oil yield / plant $(\mathrm{ml})$.

Volatile oil determination

Ten grams of full mature dry caraway fruits were ground and inserted immediately to a quick fit distillation flask. The volatile oil percentages in fruits $(10 \mathrm{~g})$ obtained from each individual plant were determined by a water distillation method described in British Pharmacopea (1963), using the following equation:

$$
\text { Volatile oil percentage }=\frac{\text { Oil volume in the graduated tube }}{\text { The weight of Air dried sample }} \times 100
$$

\section{Statistical analysis}

Estimation of variability parameters, calculated from the component of variation for the studied fruit characters in various selected entries of caraway, was done according to Snedecor and Cochran (1980). Frequency distribution was performed for each trait and the following population parameters were calculated:

1. Arithmetic mean $(x)$ : is the average mean of the trait under study. 


\section{El-Labban, H.M. et al.}

2. Range: The difference between the maximum and minimum values of the measured character.

3. Variance $\left(\mathrm{S}^{2}\right)$ : plant to plant variance was calculated by the formula for each breeding cycle:

$$
\mathrm{S}^{2} \quad=\frac{\sum \mathrm{X}^{2}-\frac{\Sigma(\mathrm{X})^{2}}{\mathrm{n}}}{\mathrm{n}-1}
$$

4. Standard deviation $(\sigma)=S$

5. Coefficient of variation C.V

$$
=\frac{\sigma}{X} \times 100
$$

\section{RESULTS AND DISCUSSION}

Results of the present study, on caraway (Carum carvi, L.), for the base population and two cycles of mass selection will be discussed each trait of the study:

\section{Plant height}

Results in Table 1 show that the range obtained for base population $\left(\mathrm{C}_{0} ; 75 \mathrm{~cm}\right)$ was greater than that for first cycle $\left(\mathrm{C}_{1} ; 66 \mathrm{~cm}\right)$ and second cycle $\left(\mathrm{C}_{2} ; 50 \mathrm{~cm}\right)$ of mass selection. The mean of the three populations, when each was compared with its standard deviation, were highly significant. However, $\mathrm{C}_{0}, \mathrm{C}_{1}$, and $\mathrm{C}_{2}$ had insignificant difference among them (t-test); according to the population mean $\left(x^{-}\right)$.

Table (1): Variability of plant height $(\mathrm{cm})$, no. of branches and weight of 100 fruit $(\mathrm{g})$ in caraway (Carum carvi, L.) after two cycles of

\begin{tabular}{|c|c|c|c|c|}
\hline cycle Mass S. & & $\begin{array}{l}\text { plant height } \\
(\mathrm{cm})\end{array}$ & No. of branches & $\begin{array}{c}\text { Weight of } 100 \text { fruit } \\
(\mathrm{g})\end{array}$ \\
\hline \multirow{5}{*}{$\mathrm{C}_{0}$} & Range & $64-139$ & $5-15$ & $0.34-1.19$ \\
\hline & $\mathrm{X}^{-}$ & 107.12 & 9.03 & 0.76 \\
\hline & $\mathrm{S}^{2}$ & 169.45 & 5.45 & 0.03 \\
\hline & S.d. & 13.02 & 2.34 & 0.17 \\
\hline & C.V \% & 12.15 & 25.85 & 22.79 \\
\hline \multirow{5}{*}{$\mathrm{C}_{1}$} & Range & $84-150$ & $7-15$ & $0.31-1.61$ \\
\hline & $\mathrm{X}^{-}$ & 112.34 & 10.31 & 0.88 \\
\hline & $S^{2}$ & 208.69 & 2.01 & 0.03 \\
\hline & S.d. & 14.45 & 1.41 & 0.18 \\
\hline & C.V\% & 12.85 & 13.75 & 19.68 \\
\hline \multirow{5}{*}{$\mathrm{C}_{2}$} & Range & $75-124$ & $8-15$ & $0.34-0.87$ \\
\hline & $\mathrm{X}^{-}$ & 101.82 & 11.55 & 0.57 \\
\hline & $\mathrm{S}^{2}$ & 129.30 & 2.74 & 0.01 \\
\hline & S.d. & 11.37 & 1.65 & 0.11 \\
\hline & C.V\% & 11.16 & 14.33 & 17.54 \\
\hline
\end{tabular}
mass selection.

$\mathrm{C}_{0}=$ Base population, $\mathrm{C}_{1}=$ The first cycle of mass selection and $\mathrm{C}_{2}=$ The second cycle of mass selection

Variances $\left(S^{2}\right)$ for the above mentioned populations were high for $C_{1}$ compared to $\mathrm{C}_{0}$ and the lowest one was obtained by $\mathrm{C}_{2}$ according to testing 
the equality of two variances ( $F$-test $=$ the larger $S^{2} /$ the smaller $\left.S^{2}\right) C_{1}$ had significant difference compared with $\mathrm{C}_{0}$ and there were significant difference between $\mathrm{C}_{0}$ and $\mathrm{C}_{2}$ in this respect. The results also indicate that, variability of the population was mostly the same for $C_{0}(12.15)$ and $C_{1}(12.85)$ and the lowest value was for $\mathrm{C}_{2}$ (11.16).

These results indicate that, the variability in plant height was reduced by two cycles of mass selection, since the range was reached about $49.0 \mathrm{~cm}$; even it is a crude measure of variability. Moreover, such reduction in

population variability confirmed in $\mathrm{C}_{2}$ by $\mathrm{S}^{2}$ and C.V. \%. Fortunately, the population mean in this cycle was not significantly reduced compared with $\mathrm{C}_{0}$ and $\mathrm{C}_{1}$.

From the previous results it could be noticed that caraway population after two cycles of mass selection became more homogenious compared to Co population.

\section{Number of branches /plant}

Results in Table 1 indicate that the range obtained for $\mathrm{C}_{2}$ was the lowest one (7.0), in comparison with $C_{0}(10.0)$ and $C_{1}(8.0)$ populations. The range of the populations became more homogenious after two cycles of mass selection. These results confirmed the other results obtained by Singh and Sastry (2003) and Tehlan et al. (2007).

The means of the three populations (Table 1) when each was compared with its standard deviation were highly significant. However, $\mathrm{C}_{0}, \mathrm{C}_{1}$ and $\mathrm{C}_{2}$ populations had insignificant difference among the mean values; however $C_{2}$ had highest number of branches (11.55) compared to $C_{1}$ (10.31) and $C_{0}$ (9.03). Concerning the performance of variance, $C_{1}$ was the lowest value followed by $\mathrm{C}_{2}$ and the largest value was obtained by $\mathrm{C}_{0}$. The difference between the three populations were significant in this regard. The results of variance reflected higher significant difference for $\mathrm{C}_{0}$ compared with $\mathrm{C}_{1}$ and/also $\mathrm{C}_{2}$ significantly higher than $\mathrm{C}_{1}$. These results were in agreement with Agnihotri et al. (1997). C.V.\% values confirmed homogeneity of $C_{1}$ population where $C_{1}$ had the lowest value (13.75\%) followed by $C_{2}(14.33)$ then $\mathrm{C}_{0}$ (25.85) was the highest one.

\section{Weight of 100 fruits}

Results in Table 1 indicate that, $C_{1}$ had the greatest range $(1.30 \mathrm{~g})$ followed by $\mathrm{C}_{0}(0.85 \mathrm{~g})$, while $\mathrm{C}_{2}$ gave the lowest range $(0.53 \mathrm{~g})$.

The mean of each cycle of selection was highly significant when compared with its standard deviation. However, $\mathrm{C}_{0}, \mathrm{C}_{1}$ and $\mathrm{C}_{2}$ had no significant difference concerning to the population mean $(x)$. For the value of variance, $C_{2}$ gave the lowest value while the values of $C_{0}$ and $C_{1}$ were equal, also there was no significant difference between $C_{0}$ and $C_{1}$, while, there was significant difference between $\mathrm{C}_{2}$ compared with $\mathrm{C}_{0}$ or $\mathrm{C}_{1}$.

That is mean that caraway population became more homogenious after two cycles of mass selection. C.V\% values indicate that $\mathrm{C}_{2}$ was more homogenious (17.54) compared with $C_{0}(22.79)$ and $C_{1}$ (19.68).

Fruit yield/plant (g)

It is clear from the results of Table 2 that, $\mathrm{C}_{0}$ gave the greatest range (39.06) followed by $C_{1}$, while $C_{2}$ gave the lowest range (26.99), indicating homogeneity in caraway yield/plant after two cycles of mass selection. 


\section{El-Labban, H.M. et al.}

There were significant differences among the three populations when the mean of each cycle of selection was compared to its standard deviation. However, there was no significant difference among mean values of the three populations. Variance, on the other side, was highly reduced by each cycle of mass selection, since $C_{0}$ had (105.79), $C_{1}$ had (61.61) and $C_{2}$ had (43.16). By testing equality of two variances $\left(F-\right.$ test $=$ the larger $S^{2} /$ the smaller $\left.S^{2}\right)$, results reflected highly significant difference for $\mathrm{C}_{0}$ compared with $\mathrm{C}_{1}$ and $\mathrm{C}_{2}$, and $\mathrm{C}_{2}$ was significantly lower than $\mathrm{C}_{0}$, and $\mathrm{C}_{1}$. Similar trend was obtained by Agnihotri et al. (1997).

The values of C.V. \% clearly indicated that, the variability in each population was reduced from $\mathrm{C}_{0}(33.76 \%)$ to $\mathrm{C}_{1}(25.02 \%)$ and $\mathrm{C}_{2}(19.09)$.

\section{Oil percentage (\%)}

The greatest range was obtained by $\mathrm{C}_{0}$ followed by $\mathrm{C}_{1}$ and finally $\mathrm{C}_{2}$. These ranges were $(2.2 \%),(1.5 \%)$ and $(1.4 \%)$, respectively, (Table 2$)$. The mean performance compared with standard deviation was highly significant for $\mathrm{C}_{0}, \mathrm{C}_{1}$ and $\mathrm{C}_{2}$ populations. On the other hand, there was no significant difference among mean values of the three populations. These results are in agreement with Kulkarni (1991) who found that an increase was happened in herb yield of davana through selection without affecting oil percentage.

The statistical analysis of results using F-test, clearly show that there were significant differences among the three populations in this regard. These results supported the other results of Koutsos et al. (2009). C.V. \% performance revealed that greatest value of C.V. \% was obtained by $\mathrm{C}_{1}$

$(21.20 \%)$ followed by $\mathrm{C}_{0}(17.69 \%)$ while the lowest one was recorded by $\mathrm{C}_{2}$ $(15.74 \%)$. This means that variation within population was reduced in this respect from $\mathrm{C}_{1}$ to $\mathrm{C}_{2}$ population.

Table (2): Variability of fruit yield/plant (g), oil percentage (\%) and oil yield/plant $(\mathrm{ml})$ in caraway (Carum carvi, L.) after two cycles of mass selection.

\begin{tabular}{|c|c|c|c|c|}
\hline cycle Mass S. & & Fruit yield/plant (g) & Oil percentage (\%) & Oil yield/plant (ml) \\
\hline \multirow{5}{*}{$\mathrm{C}_{0}$} & Range & $10.91-49.97$ & $1.3-3.5$ & $0.44-1.75$ \\
\hline & $\mathrm{X}^{-}$ & 30.47 & 2.99 & 1.27 \\
\hline & $\mathrm{S}^{2}$ & 105.79 & 0.28 & 0.09 \\
\hline & S.d. & 10.29 & 0.52 & 0.31 \\
\hline & C.V\% & 33.76 & 17.69 & 23.62 \\
\hline \multirow{5}{*}{$\mathbf{C}_{1}$} & Range & $20.50-50.92$ & $2.0-3.5$ & $0.46-1.58$ \\
\hline & $\mathrm{X}^{-}$ & 31.37 & 2.71 & 0.91 \\
\hline & $\mathrm{S}^{2}$ & 61.61 & 0.33 & 0.07 \\
\hline & S.d. & 7.85 & 0.58 & 0.26 \\
\hline & C.V \% & 25.02 & 21.2 & 29.07 \\
\hline \multirow{5}{*}{$\mathrm{C}_{2}$} & Range & $25.48-52.47$ & $2.1-3.5$ & $0.56-1.52$ \\
\hline & $\mathrm{X}^{-}$ & 34.41 & 2.46 & 0.90 \\
\hline & $\mathrm{S}^{2}$ & 43.16 & 0.15 & 0.05 \\
\hline & S.d. & 6.57 & 0.38 & 0.22 \\
\hline & C.V\% & 19.09 & 15.74 & 24.85 \\
\hline
\end{tabular}

C0 = Base population, C1 = The first cycle of mass selection and C2 $=$ The second cycle of mass selection

6. Oil yield /plant 
Results in Table 2 show that the range was gradually reduced with advancing of selection cycles. The range values were $1.31,1.12$ and 0.96 for $\mathrm{C}_{0}, \mathrm{C}_{1}$ and $\mathrm{C}_{2}$, respectively. The mean values compared with standard deviation revealed highly significant difference among $C_{0}, C_{1}$ and $C_{2}$. Concerning the variance performance, the results indicate that a higher improvement was occurred since the values reduced in each cycle to reach in final cycle of selection to (0.05). A significant difference was recorded between the three seasons. A reduction of C.V.\% values was obtained through the three cycles of mass selection of caraway plant since the lowest values in this respect was recorded by $\mathrm{C}_{2}$ population (Table 2 ).

From the previous result it could be noticed that the populations became homogenious. However, the oil yield of caraway fruits was not increased after two cycle of mass selection. Similar results were obtained by Kulkarni (1991).

The populations become homogenious but no increasing happened for oil yield after two cycle of mass selection this was agreement with Kulkarni (1991).

From the pervious mentioned results it could be noticed that there was simple increase in fruit yield of caraway through two cycles of mass selection. However, the volatile oil content in the selected plants was affected as a result of using mass selection.

As a conclusion applying two cycles of mass selection on caraway population led to reduce its variability and increase the homogeneity. Therefore, the mass selection method was recommended in order to improve caraway population and increase its homogeneity. In the future more than two cycles are needed for continuous improvement in yield/plant and the percentage of volatile oil.

\section{REFERENCES}

Agnihotri, P., S. Dashora and R. Sharma (1997). Improvement of some economical characters of fennel (Foeniculum vulgare). J. of Spices and Aromatic Crops 6(1):51-54.

Baysal, T. and D. A. J. Starmans (1999). Supercritical carbon dioxide extraction of carvone and limonene from caraway seed. J. of Supercritical Fluids, 14: 225-234.

British Pharmacopea, (1963). Determination of Volatile Oil in Drugs. Phramaceutical Press, London . W.C.I.

Dusek, K. (1992). Comparison of various genotypes in Czechoslovakia. Zahradnictvi, 19 (2):151-160.

Harro, J., B.G. Jonathan, C.J.M. Maurice and C. Rodney (1998). Biosynthesis of the Monoterpenes Limonene and Carvone in the fruit of Caraway. Plant Physiol., 117:901-912.

Koutsos, T.V., P. S. Chatzopoulou and S.T. Katsiotis (2009). Effects of individual selection on agronomical and morphological traits and essential oil of a "Greek basil" population. Euphytica, 170(3):365-370. 


\section{El-Labban, H.M. et al.}

Kulkarni, R.N. (1991). Three cycles of honeycomb selection for herb yield in davana (Artemisia pallens, Wall.). Euphytica 52: 99-102.

Kuź-mich, N.K. (1986). New Caraway variety Podolśii9. Trudy Vsesoyuznogo Nauchno Issledovatel Skogo Inslituta Efiromaslichnykn Kuĺ tar: 29-33.

National Research Centre on Seed Spices (2007). Vision-2025 National Research Centre on Seed Spices, Perspective Plan, Indian Council of Agricultural Research. pp 9-11.

Oosterhaven, K., K. J. Hartmans and J.J.C. Scheffer (1995). Inhibition of potato sprout by carvone enantiomers and their bioconversion in sprouts. Potato Res., 38 (2): 219-230.

Petraityte, N., A. Dastikaite and A. Sliesaravicius (2002). Investigation of common caraway Carum carvi, L. morphobiochemical properties stability in situ. Zemdirbyste, Mokslo, Darbai, 78: 274-282.

Singh, V. V. and E.V.D. Sastry (2003). Mass, full and half sib-selection for genetic improvement in fennel (Foeniculum vulgare Mill.). J. of Spices and Aromatic Crops. 12(2): 179-182.

Snedecor, G.W. and W.G. Cochran (1980). Statistical Method 7 th Ed., lowe state. Univ. Press, Ames lowe, USA.

Tehlan, S.K., K.K. Thakral, P.S. Partap and T.P. Malik (2007). Hisar Surbhi: A high yielding variety of coriander. Haryana J. Hortic.Sci. 36(3\&4):410411.

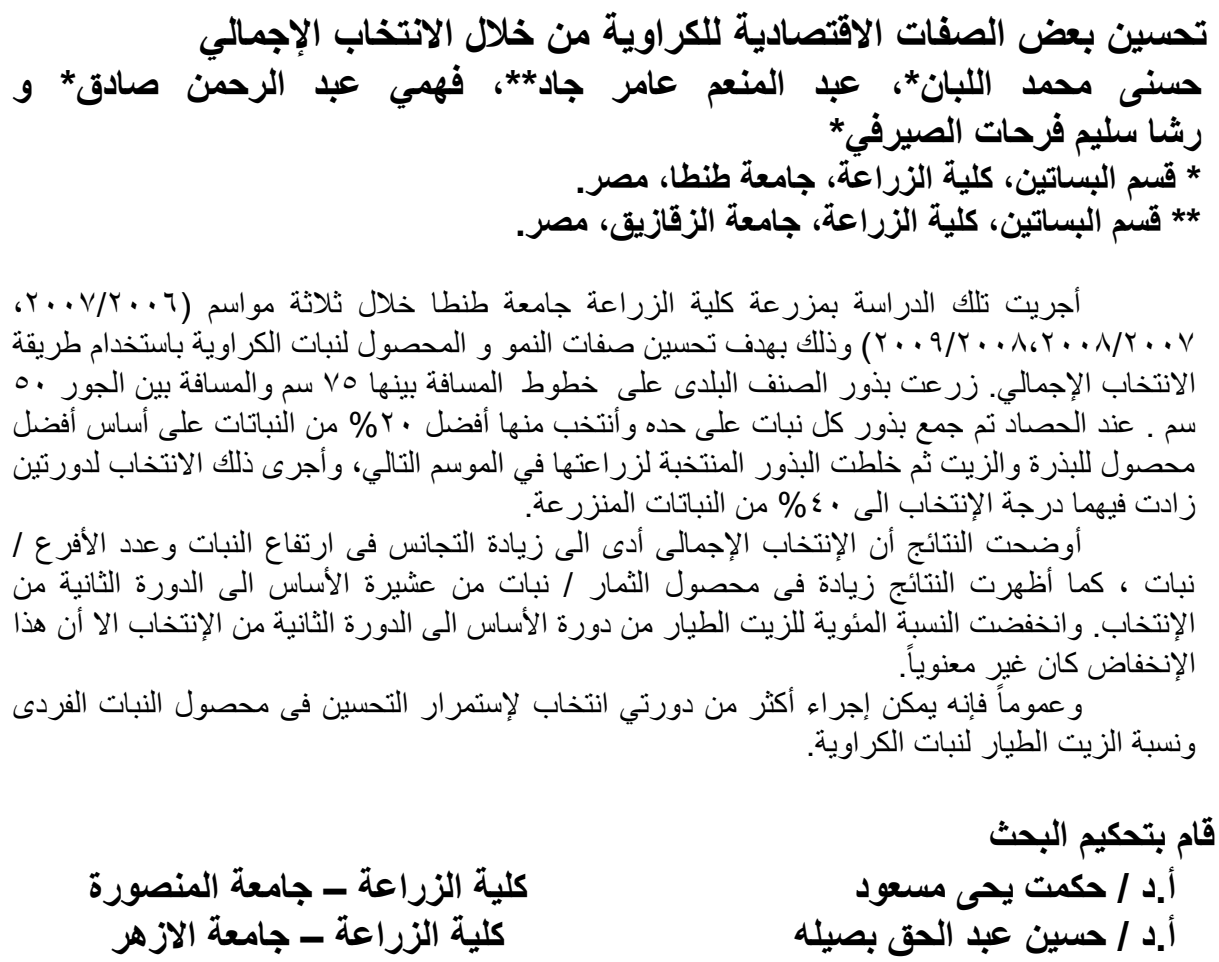

